\title{
Function of the Sex Chromosomes in Mammalian Fertility
}

\author{
Edith Heard ${ }^{1}$ and James Turner ${ }^{2}$ \\ ${ }^{1}$ Mammalian Developmental Epigenetics Group, Institut Curie, CNRS UMR3215 INSERM U934, \\ 75248 Paris Cedex 05, France \\ ${ }^{2}$ Division Stem Cell Biology and Developmental Genetics, MRC National Institute for Medical Research, \\ Mill Hill, London NW7 1AA, United Kingdom \\ Correspondence: edith.heard@curie.fr
}

\begin{abstract}
The sex chromosomes play a highly specialized role in germ cell development in mammals, being enriched in genes expressed in the testis and ovary. Sex chromosome abnormalities (e.g., Klinefelter [XXY] and Turner [XO] syndrome) constitute the largest class of chromosome abnormalities and the commonest genetic cause of infertility in humans. Understanding how sex-gene expression is regulated is therefore critical to our understanding of human reproduction. Here, we describe how the expression of sex-linked genes varies during germ cell development; in females, the inactive $X$ chromosome is reactivated before meiosis, whereas in males the $X$ and $Y$ chromosomes are inactivated at this stage. We discuss the epigenetics of sex chromosome inactivation and how this process has influenced the gene content of the mammalian $X$ and $Y$ chromosomes. We also present working models for how perturbations in sex chromosome inactivation or reactivation result in subfertility in the major classes of sex chromosome abnormalities.
\end{abstract}

$T_{p}^{\text {he }}$ he evolution of sex chromosomes from a pair of autosomes is clearly advantageous to species in enabling sexual reproduction and the genetic fitness that results, but also necessitates the coevolution of strategies to deal with unique situations that arise. These include the lack of homology between the $\mathrm{X}$ and $\mathrm{Y}$ chromosomes in the male germline in which autosomal homologs must pair and the imbalance in Xlinked gene dosage between males and females. In mammals, this sex chromosome imbalance is dealt with by inactivating one of the two X chromosomes during early female development. In the female germline, the inactive $\mathrm{X}$ chromosome is reactivated before meiosis. In the male germline, the $\mathrm{X}$ and $\mathrm{Y}$ chromosomes undergo meiotic inactivation that is linked to their unique unpaired status. This is a conserved process and has important implications for the evolution of sex chromosome gene content. In this article, we will cover these different aspects of sex chromosome behavior and function in mammals, including the role of sex chromosomes in sex determination and the behavior of the sex chromosomes during gametogenetesis, particularly in the male germline.

Editors: Paolo Sassone-Corsi, Margaret T. Fuller, and Robert Braun

Additional Perspectives on Germ Cells available at www.cshperspectives.org

Copyright (C) 2011 Cold Spring Harbor Laboratory Press; all rights reserved; doi: 10.1101/cshperspect.a002675

Cite this article as Cold Spring Harb Perspect Biol 2011;3:a002675 


\section{OVERVIEW OF SEX CHROMOSOME INFERTILITY}

Infertility, defined as failure to conceive after twelve months of regular intercourse, affects one in seven couples in the Western world and evidence suggests that its incidence is rising (De Kretzer 1997). Genetic abnormalities account for $10 \%$ and $15 \%$ of cases of infertility in females $(\mathrm{XX})$ and males $(\mathrm{XY})$, respectively (Ferlin et al. 2006). A striking feature of these abnormalities is that they frequently affect the sex chromosomes; in males, for instance, between $10 \%$ and $15 \%$ of cases of azoospermia (i.e., no sperm in the ejaculate) are caused by Y chromosome deletions (Foresta et al. 2001) and a further $10 \%$ are caused by Klinefelter syndrome (XXY) (Ferlin et al. 2006). These statistics alone provide compelling evidence that the sex chromosomes play a highly specialized role in normal germ cell development.

Sex chromosome abnormalities can be divided into two classes. The first comprises gross abnormalities that are readily identified by standard karyotypic analysis (Table 1). This includes the common sex chromosome aneuploidies-for example, Turner syndrome (XO; prevalence $0.04 \%$ ), Klinefelter syndrome (XXY; prevalence 0.1\%), and Double Y syndrome (XYY; prevalence $0.1 \%$ ) - as well as various types of X-autosome and Y-autosome translocations. Women with Turner syndrome normally have no germ cells (Speroff et al. 1991) and analysis of XO mice has found that this is because of oocyte losses at the pachytene substage of meiosis (Burgoyne and Baker 1981, 1985; Speed 1986). Klinefelter men and mice are usually sterile with a block occurring before meiosis, during the early spermatogonial divisions (Ferguson-Smith 1959; Mroz et al. 1999; Lue et al. 2001). For Double Y syndrome men, the reproductive outlook varies; the extra Y chromosome is often lost during the early spermatogonial stages and this generates XY (euploid) cell lines that can complete spermatogenesis and support fertility (Chandley 1997; Shi and Martin 2000). In XYY men and mice in which XY cell lines do not arise, infertility results, with germ cell losses occurring during pachytene and the meiotic divisions (Speed et al. 1991; Solari and Rey Valzacchi 1997; Mahadevaiah et al. 2000; Rodriguez et al. 2000).

DNA polymorphism analysis to identify the parental origin of human aneuploid conditions has shown that most cases of sex chromosome aneuploidy result from meiotic errors arising in the paternal germline (Hall et al. 2006). This stands in stark contrast to the autosomal aneuploidies (e.g., Down syndrome), which arise predominantly from maternal meiotic

Table 1. Summary of the three common sex chromosome abnormalities

\begin{tabular}{|c|c|c|c|c|}
\hline Syndrome & Karyotype & Prevalence & Somatic features & Reproductive impact \\
\hline Turner & $\mathrm{XO}^{\mathrm{a}}$ & $0.04 \%$ & $\begin{array}{l}\text { Growth retardation } \\
\text { Congenital heart disease } \\
\text { Horseshoe kidney } \\
\text { Visual impairment }\end{array}$ & $\begin{array}{l}\text { Humans: sterile } \\
\text { Mice: fertile but reduced oocyte pool and } \\
\text { reproductive lifespan }\end{array}$ \\
\hline Klinefelter & $\mathrm{XXY}^{\mathrm{b}}$ & $0.1 \%$ & $\begin{array}{l}\text { Variable } \\
\text { Tall stature } \\
\text { Gynecomastia } \\
\text { Mild developmental and } \\
\text { behavioral problems }\end{array}$ & $\begin{array}{l}\text { Humans and mice sterile unless spontaneous } \\
\mathrm{X} \text { chromosome loss }\end{array}$ \\
\hline Double Y & $\mathrm{XYY}$ & $0.1 \%$ & Tall stature & $\begin{array}{l}\text { Humans: commonly fertile because of high } \\
\text { incidence of Y chromosome loss } \\
\text { Mice: sterile because of low probability of Y } \\
\text { chromosome loss }\end{array}$ \\
\hline
\end{tabular}

\footnotetext{
${ }^{\mathrm{a}}$ Turner females are likely to be $\mathrm{XX} / \mathrm{XO}$ or $\mathrm{XY} / \mathrm{XO}$ mosaics; furthermore, some Turner females are partially monosomic.
}

${ }^{\mathrm{b}}$ Some Klinefelter men have more than two X chromosomes. 
errors (reviewed in Hassold and Hunt 2001). Double Y syndrome by definition always involves a paternal error as the embryo inherits two Y chromosomes; one study found that $84 \%$ of cases result from failure of the two Y sister chromatids to separate at the second meiotic division (Robinson and Jacobs 1999). For Klinefelter syndrome, approximately one-half of cases result from failure of the paternal $\mathrm{X}$ and $\mathrm{Y}$ chromosomes to disjoin at the first meiotic division (Thomas and Hassold 2003). Finally, in the case of Turner syndrome, $\sim 75 \%$ of affected females inherit their single X chromosome from their mother, indicating that loss of a paternal sex chromosome is the causative factor (Jacobs et al. 1997). The different types of paternal and maternal meiotic errors that give rise to these conditions are summarized in Figure 1.

The second class of sex chromosome abnormalities is the $\mathrm{Y}$ chromosome deletions, most of which occur in the long arm of the $Y$ chromosome at Yq11 (Tiepolo and Zuffardi 1976). These are difficult to detect cytogenetically and as a result are usually diagnosed by PCR-based methods. Three common Y deletions that cause azoospermia are the $A Z F$ (azoospermia factor) deletions $A Z F a, A Z F b$, and $A Z F c$ (Vogt et al. 1996; Vogt 2005), named according to their subchromosomal position and associated spermatogenic phenotype. $A Z F a$ deletions affect proximal Yq11 and result in a complete absence of germs cells, whereas $A Z F b$ deletions affect the middle of Yq11 and cause a block during meiosis. AZFc deletions, which are the most common, arising in roughly 1 in 4000 males (Kuroda-Kowaguchi et al. 2001), cause arrest in late spermatogenesis with small numbers of aberrantly shaped sperm being produced. A fourth type of Y chromosome deletion, which removes distal Yq sequences and also results in the formation of a mirror image or isodicentric $\mathrm{Y}$ chromosome with duplicated proximal $\mathrm{Yp}$ and centromeric sequences, is present in $8 \%$ of azoospermic men (Jacobs and Ross 1966; Hsu 1994; Lange et al. 2009). Y chromosomal deletions are also associated with infertility in mice; Yp deletions cause a block during early spermatogenesis, whereas Yq deletions give rise to sperm head abnormalities (Mazeyrat et al. 2001; Mitchell 2004).

The discovery of these $\mathrm{Y}$ chromosome deletions and their deleterious effects on spermatogenesis created a paradigm shift in our understanding of sex chromosome genetics, because they countered the long-held view that Y chromosomes are "genetic deserts" containing few functional genes (Marshall Graves 2002). This belief was based on the fact that the $\mathrm{Y}$ chromosome has no homologous partner with which to undergo recombination-related repair (Charlesworth and Charlesworth 2000). Without such a partner, mutations affecting the Y chromosome would essentially be irreparable and this would lead to the stepwise decay of Y-linked genes over evolutionary time, and possibly even to the eventual extinction of the Y chromosome (Marshall Graves 2002). However, analysis of the sequence of the human $\mathrm{Y}$ chromosome has revealed that it contains at least 78 protein-coding genes (Skaletsky et al. 2003). The $Y$ chromosome also contains a large number of direct repeats and inverted repeats, or palindromes. Palindromes, which comprise two arms of highly similar ( $>99.9 \%)$ nucleotide sequence separated by a small spacer region, contain many of the critical spermatogenesis genes and these are therefore present as multiple copies (Skaletsky et al. 2003). The human $\mathrm{Y}$ chromosome contains eight palindromes ranging in size from $30 \mathrm{~kb}$ to $2.9 \mathrm{MB}$ and together, they occupy one quarter of the euchromatic DNA content. These palindromes provide a counterpoint to $\mathrm{Y}$ chromosome decay, because mutations occurring in genes in one arm of the palindrome can be corrected using the nonmutated copy within the other arm. This is achieved using gene conversion; the nonreciprocal transfer of information from one DNA duplex to another (Szostak et al. 1983). Gene conversion events occur between palindromes at a high frequency, estimated at one gene conversion per 600 nucleotides per newborn male (Rozen et al. 2003).

An alternative outcome of recombination is reciprocal exchange or crossover formation, which can also occur between direct repeats 
E. Heard and J. Turner

A $\quad X Y$

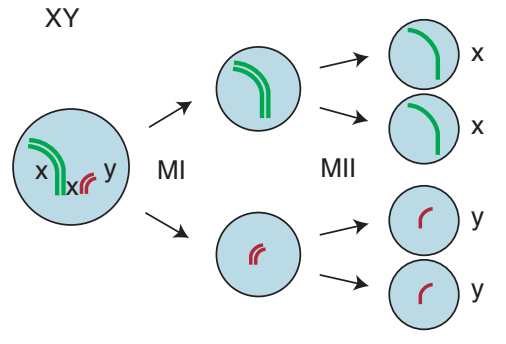

C $\quad X X Y$

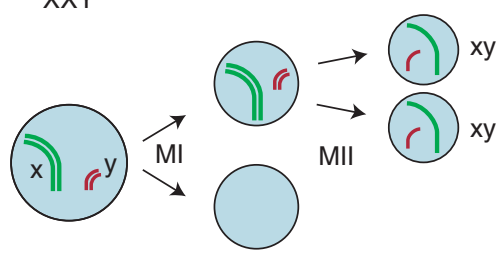

E $\quad X X$

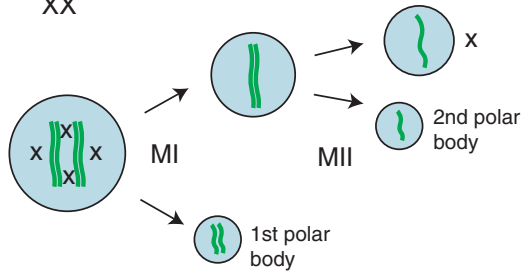

G $\quad X X Y$

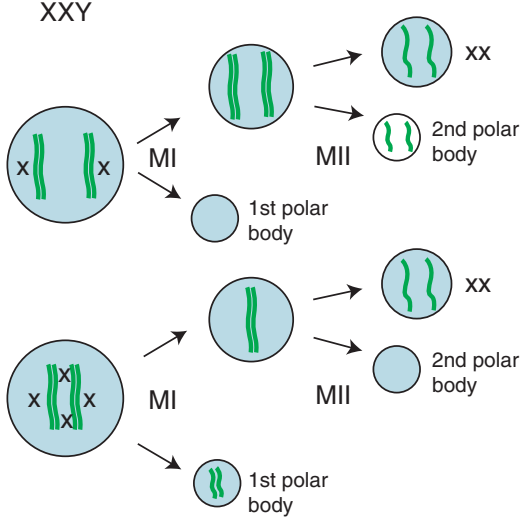

B $X Y Y$

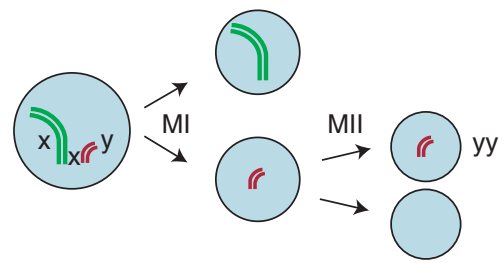

D XO
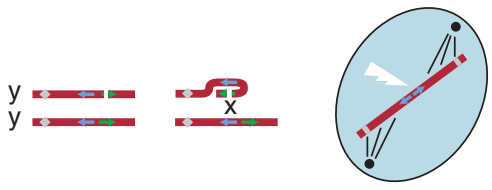

F $\quad x O$
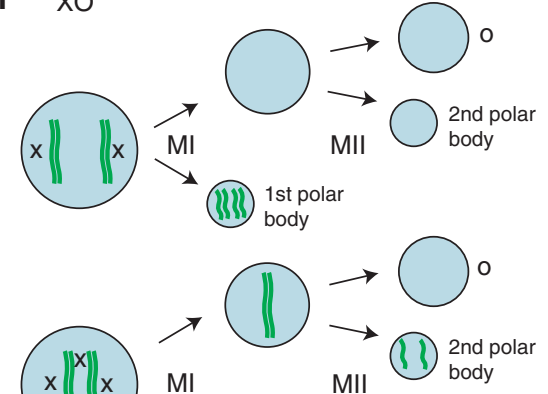

Figure 1. The mechanisms by which errors in meiosis give rise to chromosome abnormalities. $(A)$ During normal male meiosis, the $\mathrm{X}$ and $\mathrm{Y}$ chromosomes synapse and crossover within the distal pseudoautosomal region; this crossover is essential in ensuring normal homologous segregation during the first meiotic division (MI). The resulting secondary spermatocytes then enter the second meiotic division (MII), during which sister chromatids segregate, thereby generating four haploid products each containing a single sex chromosome. (B) Nondisjunction of the two Y sisters to segregate at MII results in YY spermatids; these give rise to XYY sons at fertilization. $(C)$ Nondisjunction of $\mathrm{X}$ and $\mathrm{Y}$ homologs to segregate at MI, either because of failed establishment or maintenance of crossing over, followed by normal sister separation at MII results in XY spermatids; these give rise to XXY sons at fertilization. (D) Formation of a DNA double-strand break in one of two Y sister chromatids followed by crossing over between palindromes of sisters results in an isodicentric Y chromosome. (See facing page for legend.) 
Function of the Sex Chromosomes in Mammalian Fertility

and between palindromes. These recombination events result in loss of genetic information and as such are the principle mechanism by which $A Z F$ deletions and isodicentric Y chromosomes originate (Fig. 1) (Blanco et al. 2000; Kamp et al. 2000; Sun et al. 2000; KurodaKawaguchi et al. 2001; Repping et al. 2002, 2003; Lange et al. 2009). In the case of isodicentric $Y$ chromosomes, impaired fertility is not the only deleterious outcome of this form of recombination. Isodicentric Y chromosomes carry two centromeres that can form a bipolar spindle attachment during cell division. This results in breakage of the $\mathrm{Y}$ chromosome during anaphase and subsequently to $\mathrm{Y}$ chromosome loss (Fig. 1) (Lange et al. 2009). If this loss occurs in the male germline, sperm will be produced that have no sex chromosome and this can lead to formation of $\mathrm{XO}$ embryos at fertilization. Thus, palindrome-palindrome recombination could give rise to a significant proportion of cases of Turner syndrome (Fig. 1) (Lange et al. 2009).

The mechanism by which $\mathrm{Y}$ chromosome deletions cause infertility is straightforward; these deletions remove Y-linked genes that are essential for germ cells to transit through defined stages of spermatogenesis. However, the way in which sex chromosome aneuploidy causes infertility has, until recently, remained mysterious. In this case a major factor appears to be linked to the activity of the $\mathrm{X}$ chromosome and its unique dynamics of reactivation in the female germline and inactivation in the male germline. These processes are described in the following sections.

\section{SEX CHROMOSOME EXPRESSION DURING MALE AND FEMALE GAMETOGENESIS}

Our knowledge of the dynamics and behavior of the sex chromosomes during human gametogenesis is limited, for obvious reasons. In mice on the other hand, extensive studies have been performed on germ cell development. In both males and females, primordial germ cells (PGCs) originate from the proximal epiblast of the postimplantation mouse embryo at around E7.25 (Saitou 2009). In males, the single $\mathrm{X}$ chromosome is active in newly formed PGCs; however, in females one of the Xs is initially inactive in PGCs (Fig. 2) (Xi; Chuva de Sousa Lopes et al. 2008). Indeed, random X chromosome inactivation (XCI) initiates well before this stage, in epiblast precursor cells at around E5.5 (McMahon and Monk 1983). During XCI, up-regulation of Xist RNA leads to the onset of gene silencing across the length of the X chromosome. Xist RNA induces changes in chromosome organization and results in recruitment of histone modifying enzymes, principally the PRC1 and PRC2 complexes, which catalyze mono-ubiquitylation of histone H2A at lysine 119 (H2AK119u1) (de Napoles et al. 2004; Fang et al. 2004) and trimethylation of histone $\mathrm{H} 3$ at lysine 27 (H3K27me3) (Silva et al. 2003; Plath et al. 2003), respectively. The inactive $\mathrm{X}$ is further modified by DNA methylation at promoters. One $\mathrm{X}$ chromosome is thus globally inactive by the time PGCs first start to appear during female embryogenesis, which implies that all of the above epigenetic changes must be reversed during the reprogramming

Figure 1. (Continued) This forms a bipolar attachment during cell division and is subsequently broken and lost. In principle, this form of recombination could take place during spermatogonial mitosis, meiosis, or even in the early embryo; all of which will give rise to XO daughters. (E) During normal female meiosis, synapsis and crossover formation are followed by dictyate arrest. The first meiotic division at puberty generates a polar body and a secondary oocyte; the second at fertilization generates a second polar body and a single haploid product. $(F)$ Nondisjunction of either homologs at MI or sisters at MII has similar effect, with haploid products with no sex chromosome ("O" gametes) generated. These generate XO daughters at fertilization. $(G)$ Similar meiotic errors give rise to XX haploid products and thereafter XXY sons; the outcome depends on whether the nondisjoined chromosomes end up in the oocyte or the polar body. Although not detailed here, some cases of XXYand $\mathrm{XYY}$ arise during embryogenesis as a result of mitotic nondisjunction of the maternally inherited $\mathrm{X}$ and paternally inherited Y, respectively. 


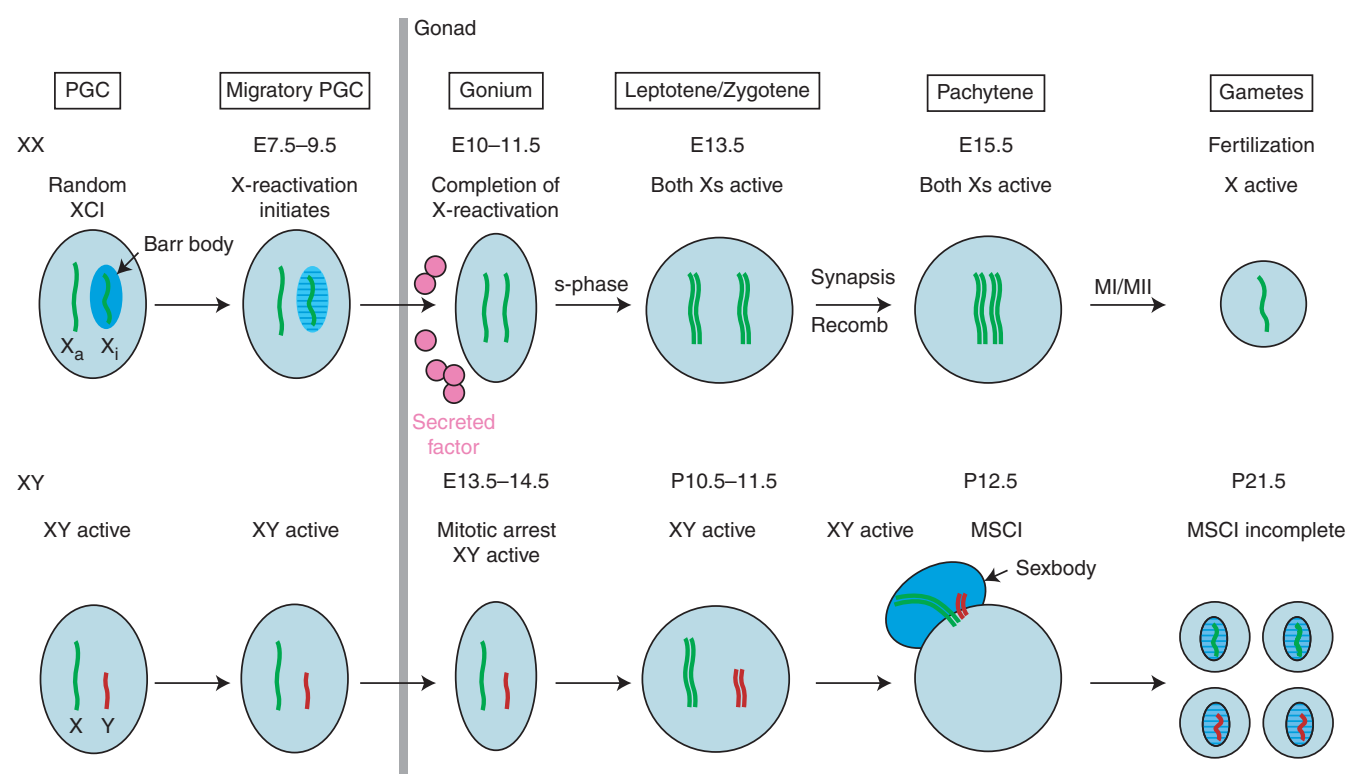

Figure 2. Sex chromosome activity during female and male germ cell development. Female PGCs have one inactive and one active $\mathrm{X}$ chromosome. $\mathrm{X}$ chromosome reactivation occurs during migration of PGCs to the genital ridge between E7.5 and E9.5; full reactivation is achieved after colonization of the genital ridge between E10 and E11.5 in response to an unknown secreted factor/s. Female germ cells then enter meiosis. Meiotic DNA replication (S-phase) is followed by leptotene (E13.5) when DNA DSBs are formed. Chromosomes initiate synapsis during zygotene (E14) and the completion of synapsis heralds the onset of pachytene (E15.5). Throughout and after meiosis the $\mathrm{X}$ chromosomes remain active. In males, the $\mathrm{X}$ and $\mathrm{Y}$ are active in male throughout early germ cell development. In contrast to females, male germ cells undergo mitotic arrest from E13.5 to E14.5 until shortly after birth, when the spermatogonial divisions begin. The $\mathrm{X}$ and $\mathrm{Y}$ remain active until pachytene, when meiotic sex chromosome inactivation (MSCI) takes place. After meiosis, mean expression from the X chromosome remains low compared to autosomes, but at this stage genes are not silenced as completely as they are during pachytene.

that occurs in the female germline (Chuva de Sousa Lopez et al. 2008).

Following their specification, PGCs divide and migrate through the hindgut endoderm, eventually colonizing the gonad between E10 and E11.5 (Fig. 2) (Saitou 2009). During this time, the $\mathrm{Xi}$ in female PGCs is reactivated. $\mathrm{X}$ chromosome reactivation was originally believed to occur after germ cells enter the gonad, just before the initiation of meiosis (Kratzer and Chapman 1981; Monk and McLaren 1981; Tam et al. 1994; Nesterova et al. 2002). However, more recent analyses have found that reactivation initiates much earlier during PGC development, with Xist RNA, PRC2, and H3K27me3 being lost from $\mathrm{Xi}$ during the migratory phase (E7.5-9.5) (de Napoles et al. 2007; Sugimoto and Abe 2007; Chuva de Sousa
Lopes et al. 2008). Intriguingly, Xi reactivation is dependent on factors secreted by the $\mathrm{XX}$ urogenital ridge rather than being an intrinsic property of female germ cells (Chuva de Sousa Lopes et al. 2008). The nature of the secreted factors that enable Xi reactivation are unknown however. Following entry into the gonad, male and female germ cells exhibit a striking sexual dimorphism in their behavior; germ cells in the male form prospermatogonia and enter mitotic arrest between E13.5 and E14.5 (reviewed by McLaren 2003), whereas female germ cells enter meiosis. Throughout meiosis, both $\mathrm{X}$ chromosomes within the oocyte remain active (Fig. 2) (Epstein 1969; Gartler et al. 1975; Andina 1978).

Shortly after birth, prospermatogonia in the male gonad resume mitosis and initiate 
spermatogenesis (Russell et al. 1990). Spermatogenesis comprises three broad phases; spermatogonial proliferation, meiosis, and spermiogenesis, together lasting 35 and 64 days in mouse and man, respectively (Heller and Clermont 1963; Russell et al. 1990). During the first phase, spermatogonia undergo approximately ten mitotic divisions, forming A, Intermediate and then finally B type-spermatogonia. Analyses of transcription across the X chromosome by microarray analysis (Khil et al. 2004; Namekawa et al. 2006) and RNA fluorescence in-situ hybridization (RNA FISH; Turner et al. 2006; Mueller et al. 2008) have shown that the $\mathrm{X}$ and $\mathrm{Y}$ are active during these stages, with the collective mean expression level of genes on the $\mathrm{X}$ chromosome being approximately equal to that of the autosomes (Fig. 2) (Mueller et al. 2008). In spite of this similarity in expression levels, the $\mathrm{X}$ chromosome is more densely populated with spermatogonially expressed genes when compared to the autosomes. This is consistent with the evolutionary concept of "sexually antagonistic" genes (Fisher 1931), which are predicted to become enriched on the $\mathrm{X}$ chromosome because of its hemizygous state in males (see later for more detailed description; Wang et al. 2001; Khil et al. 2004).

After the spermatogonial divisions germ cells become spermatocytes and enter meiosis. Meiosis is a highly specialized cell division that serves to convert diploid cells into haploid daughters and to allow the exchange of genetic information between maternal and paternal homologs (Zickler and Kleckner 1999). During this phase, the $\mathrm{X}$ and $\mathrm{Y}$ chromosomes become transcriptionally silenced, a process called meiotic sex chromosome inactivation (MSCI) (McKee and Handel 1993; Turner 2007), and form the heterochromatic "sex body" (Fig. 2) (Solari 1974).

When exactly during meiosis does MSCI take place? Early cytological studies found that the $\mathrm{X}$ and $\mathrm{Y}$ chromosomes are heterochromatic from as early as meiotic S-phase (Odartchenko and Pavillard 1970) and semiquantitative RTPCR experiments concluded that repression of specific X-linked genes initiated in leptotene and/or zygotene (Singer-Sam et al. 1990;
McCarrey et al. 1992). Analyzing gene expression during these very early meiotic stages is inherently difficult because transcription levels throughout the genome, as assayed by tritiated uridine uptake (Monesi 1965) and Cot1 RNA FISH (Turner et al. 2005) are very low. This is possibly the result of the high degree of chromosome compaction that accompanies DNA double-strand break (DSB) formation and repair (Hunter et al. 2001). However, the limited data available for gene-specific RNA FISH for $\mathrm{X}$ - and Y-linked genes indicate that silencing is initiated at early pachytene (Turner et al. 2006), when modifications necessary for MSCI (e.g., $\gamma \mathrm{H} 2 \mathrm{AX}$ ) appear on the sex chromosomes (Mahadevaiah et al. 2001; Fernandez-Capetillo et al. 2003).

Following the two meiotic divisions, newly formed haploid round spermatids undergo a protracted period of differentiation into mature spermatozoa, accompanied by the replacement of histones with transition proteins and, thereafter, protamines. For a number of years, the transcriptional state of the $\mathrm{X}$ and $\mathrm{Y}$ chromosomes during this period remained unclear; anecdotal evidence focusing on specific sexlinked genes reported expression in purified round spermatids populations (Hendriksen et al. 1995; Hendriksen 1999), and this fostered the view that MSCI was restricted to meiosis. However, this dogma was challenged when it was noted that repressive chromatin marks, such as histone $\mathrm{H} 3$ dimethylated at lysine 9 (H3K9me2) and the heterochromatin-associated CBX1 protein remain associated with the $\mathrm{X}$ and $\mathrm{Y}$ during the meiotic divisions and into early round spermatid development (Khalil et al. 2004).

Shortly thereafter, four studies provided further evidence that the repressive effects induced by MSCI are retained postmeiosis (Fig. 2) (Greaves et al. 2006; Namekawa et al. 2006; Turner et al. 2006; Mueller et al. 2008). The X chromosome was found to be conspicuously heterochromatic and transcription poor, based on Cot1 RNA FISH and RNA polymerase II staining throughout round and elongating spermatid differentiation (Greaves et al. 2006; Namekawa et al. 2006; Turner et al. 2006). 
Microarray analysis showed that the mean expression level for X-linked genes, which predictably dropped between spermatogonia and pachytene as a result of MSCI, remained low in round spermatids (Namekawa et al. 2006; Mueller et al. 2008). However, an important detail became apparent when the mean $\mathrm{X}$-gene expression levels in spermatids and pachytene were scrutinized more closely. Although low, the mean X-expression level in round spermatids was found to be slightly higher than in pachytene (Mueller et al. 2008). This provided preliminary evidence that silencing of the $\mathrm{X}$ chromosome in spermatids might not be as complete as during pachytene. This was subsequently borne out by RNA FISH data; although $\mathrm{X}$-linked genes were found to be robustly silenced in pachytene cells, the same genes showed variable levels of reactivation in spermatids; some remained silent whereas others reactivated (Mueller et al. 2008).

In summary, in female germ cells the inactive $\mathrm{X}$ chromosome is reactivated before meiosis and thereafter remains active, whereas in males the $\mathrm{X}$ chromosome is inactivated during meiosis and then retains a significant but not complete level of silencing during spermiogenesis (Fig. 2).

\section{FUNCTION AND MECHANISM OF MEIOTIC SEX CHROMOSOME INACTIVATION}

In female mammals, XCI serves to equalize the levels of X-linked products with that in males (Heard and Disteche 2006). In contrast, the function of MSCI remains mysterious, although it is assumed to be an essential process because of its conservation across the animal kingdom (McKee and Handel 1993). Insight into the processes that drive MSCI in mammals came from an unlikely source, the fungus Neurospora crassa. Shiu and colleagues (2001) were studying the effects of different types of mutation of the Asm-1 (Ascospore maturation-1) gene on the development of the haploid products of meiosis, called ascospores. They noted that heterozygous loss of function mutations in Asm-1 resulted in inviability in those ascospores that inherited this mutation, whereas those ascospores inheriting the wild-type allele were unaffected. When heterozygous for a complete deletion of Asm-1 all the resulting ascospores, including those with the wild type Asm-1 allele, were inviable. Thus, deletion of one Asm-1 allele had rendered the second allele susceptible to silencing. This led the investigators to propose that physical "pairing" between genes on different homologs during meiosis was required for them to be expressed.

Might a similar "meiotic silencing" process be operating in mammals? During normal male meiosis, the autosomes pair/synapse fully whereas the single $\mathrm{X}$ and $\mathrm{Y}$ chromosomes are largely nonhomologous and therefore remain unsynapsed. This asynapsis could trigger gene silencing across the $\mathrm{X}$ chromosome, resulting in MSCI. Two key observations showed that MSCI was indeed driven by the unsynapsed state of the sex chromosomes. First, when either the $\mathrm{X}$ or the $\mathrm{Y}$ chromosomes were provided with a pairing partner, this prevented them being silenced (Turner et al. 2006). For instance, in XYY males, the two Y chromosomes form a completely synapsed bivalent, and as a result continue to express Y-linked genes during pachytene, when MSCI should normally have been completed. This escape from MSCI may be directly responsible for the pachytene arrest observed in XYY mice and men (Turner 2006). Second, in male mice carrying $X$ autosome or autosome-autosome translocations, both of which prevent synapsis between autosomal homologs, the resulting unsynapsed autosomal regions became transcriptionally silenced, just like the $\mathrm{X}$ and $\mathrm{Y}$ chromosomes in normal male pachytene cells (Baarends et al. 2005; Turner et al. 2005). Thus, any unpaired meiotic chromosome was silenced if it failed to synapse. Studies in other organisms, principally Caenorhabditis elegans, has shown that asynapsis of the $\mathrm{X}$ chromosome is a universal driving force for MSCI (Bean et al. 2004).

Interestingly, meiotic silencing is not restricted to the male germline. In organisms in which the female is the heterogametic sex, for instance birds, the partly synapsed ZW sex bivalent is silenced during oogenesis, whereas the fully synapsed $\mathrm{ZZ}$ bivalent remains active 
during spermatogenesis (Schoenmakers et al. 2009). In female mice, meiotic silencing is also seen when chromosome synapsis is impaired. In $\mathrm{XX}$ females the two $\mathrm{X}$ chromosomes are fully synapsed and transcriptionally active throughout pachytene, but in XO females, the single X chromosome becomes transcriptionally silenced during pachytene (Baarends et al. 2005; Turner et al. 2005). Similarly, in human oocytes, unsynapsed autosomes, such as the additional copy of chromosome 21 in Down syndrome, are silenced (Garcia-Cruz et al. 2009).

A critical step in the initiation of MSCI is phosphorylation of histone $\mathrm{H} 2 \mathrm{AX}$ at serine-139, generating $\gamma \mathrm{H} 2 \mathrm{AX}$ (Rogakou et al. 1999). Indeed, $H 2 A X$-null male mice are sterile, with a block midway through pachytene, and MSCI fails to initiate (Fernandez-Capetillo et al. 2003). H2AX is abundantly expressed in the testis and the appearance of $\gamma \mathrm{H} 2 \mathrm{AX}$ throughout the XY chromatin at early pachytene is temporally linked to the formation of the sex body (Mahadevaiah et al. 2001) as well as to silencing of $\mathrm{X}$ - and Y-linked genes as determined by RNA FISH (Turner et al. 2006). In mitotic cells, $\mathrm{H} 2 \mathrm{AX}$ phosphorylation is achieved through the combined kinase activities of Atm, Atr, and DNA-PK (Fillingham et al. 2006). In mammals, both ATR (Turner et al. 2004) and ATM (Hamer et al. 2004) has been localized to the XY bivalent during the initiation of MSCI, but MSCI initiates normally in mice with mutations in Atm (Bellani et al. 2005; Turner et al. 2005), suggesting either that ATR acts alone in H2AX phosphorylation or that these kinases can compensate for one another in MSCI. Further evidence implicating ATR in MSCI has been provided by studies of mice with a mutation in Brcal (Turner et al. 2004). BRCA1 also localizes to the XY bivalent at the onset of MSCI, and in Brcal mutants ATR localization to the $\mathrm{X}$ and $\mathrm{Y}$ chromosomes is impaired. This impairment correlates with defective H2AX phosphorylation and MSCI failure.

Other epigenetic modifications more classically associated with chromatin silencing also become enriched on the sex chromosomes during the initiation of MSCI, most notably H3K9me2 (Peters et al. 2001; Khalil et al. 2004) and histone $\mathrm{H} 3$ trimethylated at lysine 9 (H3K9me3) (Greaves et al. 2006), as well as SUMO-1 modification of an as-yet unidentified chromatin target (Rogers et al. 2004; Vigodner and Morris 2005). Whether these modifications are essential for MSCI is unclear; SUMO-1 enrichment precedes H2AX phosphorylation and is therefore a very early event in the inactivation process (Vigodner 2009). Other histone modifications and variants-for example, H2AK119u1 (Baarends et al. 1999), hypoacetylated histones $\mathrm{H} 3$ and $\mathrm{H} 4$ (Khalil et al. 2004), H2AFY (Hoyer-Fender et al. 2000), H2AZ (Greaves et al. 2006), CBX1 (Motzkus et al. 1999; Metzler-Guillemain et al. 2003), and CBX3 (Metzler-Guillemain et al. 2003) appear after $\mathrm{H} 2 \mathrm{AX}$ phosphorylation and therefore may be involved in the maintenance of silencing. Recently, a study has found that the $\mathrm{XY}$ bivalent is dramatically remodeled following the initiation of MSCI; with H3.1/2 nucleosomes being evicted and replaced by H3.3 (van der Heijden et al. 2007). This exchange correlates with the transient disappearance and reappearance of $\mathrm{H} 3$-linked inactivating histone marks and is thought to be linked to the requirement to reactivate selected $\mathrm{X}$-linked genes in the postmeiotic period (van der Heijden et al. 2007).

The mechanisms underlying the maintenance of $\mathrm{X}$ chromosome repression during spermiogenesis are poorly understood. A new study implicates a Y-linked gene in this process (Cocquet et al. 2009). The long arm of the mouse Y chromosome (Yq) comprises at least four gene families each present as multiple copies (Toure et al. 2004, 2005). One of these is Sly (Sycp3-like Y-linked), which encodes a protein related to the synaptonemal complex protein SYCP3 (Reynard et al. 2009). Deletions of Yq cause abnormal sperm head morphogenesis and infertility, and this is associated with increased mRNA levels of X-linked and Yplinked genes in developing spermatids (Ellis et al. 2005). This elevation in mRNA levels is caused by increased nascent transcription of $\mathrm{X}$ and $\mathrm{Y}$ genes and therefore reflects a 
chromatin-mediated defect in the maintenance of XY silencing (Reynard and Turner 2009). Accordingly, repressive histone marks, including $\mathrm{H} 3 \mathrm{~K} 9 \mathrm{me} 3$ and $\mathrm{CBX} 1$, are reduced or absent on the spermatid X and Y chromosomes in Yq mutants (Reynard and Turner 2009). Interestingly, SLY protein localizes to both the $\mathrm{X}$ and the Y chromosomes during spermatid development, and mice depleted in SLY through small interfering RNA-based approaches show exactly the same sex chromatin defects as males with Yq deletions (Cocquet et al. 2009). Thus, SLY is a major regulator of $\mathrm{X}$ chromosome repression in the mouse germline. The Sly gene family is found only mice; it would therefore be interesting to study to what extent $\mathrm{X}$ chromosome silencing is maintained during postmeiotic development in other mammals.

\section{MEIOTIC SEX CHROMOSOME INACTIVATION AND X CHROMOSOME GENE CONTENT}

Recent studies have shown that MSCI has had a profound effect on the gene content of the $\mathrm{X}$ chromosome. One would predict that MSCI and repression of the $\mathrm{X}$ chromosome during spermiogenesis would drive meiotic and postmeiotic genes off the $\mathrm{X}$ chromosome, and this is indeed the case. Microarray-based analysis in Drosophila (Parisi et al. 2003; Ranz et al. 2003), C. elegans (Reinke et al. 2004), and mice (Khil et al. 2004) has shown that the $X$ chromosome is depleted in spermatogenesis genes. This has been accompanied in Drosophila and mice by an excess of retrotransposition of genes off the $\mathrm{X}$ chromosome and onto autosomes (Betran et al. 2002; Emerson et al. 2004; Wang 2004; Khil et al. 2005). The resulting retroposed copies are expressed specifically during and after MSCI, suggesting that they compensate for the silencing of their X-linked counterparts (Wang 2004).

At first, these findings seem at variance with the predictions of Rice (1984), who argued that genes involved in spermatogenesis should actually be enriched on the $\mathrm{X}$ chromosome. This argument was based on the concept of "sexually antagonistic" alleles (Fisher 1931); those that enhance reproductive fitness in one sex but diminish it in the other. Rice (1984) argued that a recessive mutation in an $\mathrm{X}$-linked gene that conferred a reproductive advantage in males but was deleterious to females would spread rapidly in a population, because it would be immediately apparent phenotypically because of its hemizygous state. Eventually, females would arise that are homozygous for the mutation. This would impair their reproductive capacity, and this in turn would lead to the evolution of modifiers that restrict the expression of the gene to the testis. Perhaps paradoxically, the $\mathrm{X}$ chromosome is also expected to be enriched in genes involved in oogenesis (Rice 1984), because the X chromosome spends two-thirds of its evolutionary time in females, thereby increasing the chance that a mutation conferring a female reproductive advantage will become fixed. An enrichment of femalebiased genes on the $\mathrm{X}$ chromosome has indeed been found both in Drosophila (Ranz et al. 2003) and mice (Khil et al. 2004), although not in humans (Lercher et al. 2003).

So how can the apparent depletion of spermatogenesis genes on the mouse $\mathrm{X}$ chromosome be reconciled with Rice's prediction? The answer, it appears, lies in the specific substage of spermatogenesis being scrutinized. Although the $\mathrm{X}$ chromosome appears to be depleted in testis-expressed genes when the testis is considered as a whole entity, studies on specific spermatogenic subtypes painted a different picture. For instance, in a screen designed to identify spermatogonial-specific genes, Wang et al. (2001) found that one-third of the 36 genes identified mapped to the $\mathrm{X}$ chromosome, suggesting that this chromosome plays a predominant role in spermatogonial development. A similar finding was made later by Khil et al. (2004); in their analysis spermatogonially expressed genes were overrepresented on the $\mathrm{X}$ chromosome, but genes expressed during meiosis and spermiogenesis were underrepresented. Because these later cell types outnumbered spermatogonia when the testis was considered as a whole, the overall impression was that the $\mathrm{X}$ chromosome was depleted in spermatogenesis genes. 
So is this the complete picture? Probably not; the conclusion of Khil et al. (2004) that spermatid-expressed genes are underrepresented on the $\mathrm{X}$ chromosome was based on analysis of single-copy genes. A recent study has found that the $\mathrm{X}$ chromosome is enriched in multiple-copy genes and that most of these genes are expressed exclusively in spermatids (Mueller et al. 2008). Together, these genes represent 33 gene families, totaling 273 genes or $18 \%$ of the total protein-coding X-gene complement. Mueller et al. (2008) noted that in contrast to single-copy genes, which showed reactivation in only a small proportion of spermatids, multiple-copy genes were expressed in high numbers of spermatids, and the expression levels of multiple-copy genes were similar to those of autosomal, spermatid-expressed genes. They concluded that gene amplification antagonizes the repressive chromatin environment on the spermatid X chromosome.

Furthermore, most studies on X-gene expression have focused on protein-coding genes. Recent reports have now examined the expression of miRNAs during spermatogenesis (Ro et al. 2007; Song et al. 2009). Interestingly testis-expressed miRNAs also preferentially map to the $X$ chromosome (Ro et al. 2007) and, more strikingly, around $80 \%$ of these Xlinked miRNAs are expressed during pachytene (Song et al. 2009). This finding is unprecedented, as it represents the first example of a class of genes that are able to evade MSCI. These genes are proposed to play roles in either meiosis or in MSCI itself (Song et al. 2009).

\section{$X$ CHROMOSOME REACTIVATION AND MEIOTIC SILENCING AS CAUSES OF INFERTILITY}

The studies outlined on $\mathrm{X}$ chromosome reactivation in the female germline and MSCI in the male germline provide a framework for understanding how sex chromosome aneuploidy causes infertility (Fig. 3). X chromosome reactivation occurs in the female during germ cell development, but it also occurs in males with two X chromosomes, notably XXY/Klinefelter mice (Mroz et al. 1999). However, the exact timing of $\mathrm{X}$-reactivation in males is unclear. Although two active X chromosomes are clearly tolerated by female germ cells, the situation may be different in males, because in this case germ cells will express a double dosage of spermatogonial-specific X-linked genes, in addition to "housekeeping" X-linked genes. Any toxic effect caused by this expression would be expected to manifest itself during spermatogonial development, and this fits well with the early germ cell arrest seen in XXY men and mice (Fig. 3) (Ferguson-Smith 1959; Mroz et al. 1999; Lue et al. 2001).

In sex chromosome aneuploid models that germ cell arrest occurs later, during pachytene (e.g., Turner syndrome, X- or Y-autosome translocations), meiotic silencing could be a contributing factor. In X- or Y-autosome translocations, and even autosome-autosome translocations, the disruption to autosomal synapsis results in silencing of all genes located within the unsynapsed autosomal segments via meiotic silencing. Clearly, if one or more of these genes are essential for progression through pachytene, then this will result in germ cell arrest. Pachytene is a stage during which abundant autosomal transcription is known to occur (Monesi 1965; Turner et al. 2005). The meiotic silencing hypothesis fits well with the observation that small amounts of autosomal asynapsis do not invoke arrest whereas larger unsynapsed autosomal segments do (Ashley 2000); the larger the unsynapsed chromosome region, the higher the probability that it will contain a meiosis-critical gene. The model is also particularly compelling when considering $\mathrm{XO}$ oocytes; in this case the entire X chromosome will be silenced, rendering the oocyte nullizygous for X-linked gene products (Fig. 3). The timing of oocyte loss in $\mathrm{XO}$ females fits well with that of the initiation of meiotic silencing (i.e., during pachytene [Burgoyne and Baker 1981, 1985]).

A converse argument can be used to explain meiotic losses in XYY mice and men. In XYY mice, a significant proportion of early pachytene cells exhibit complete YY synapsis and this allows escape of $\mathrm{Y}$ genes from MSCI (Turner et al. 2006). Interestingly, these cells 


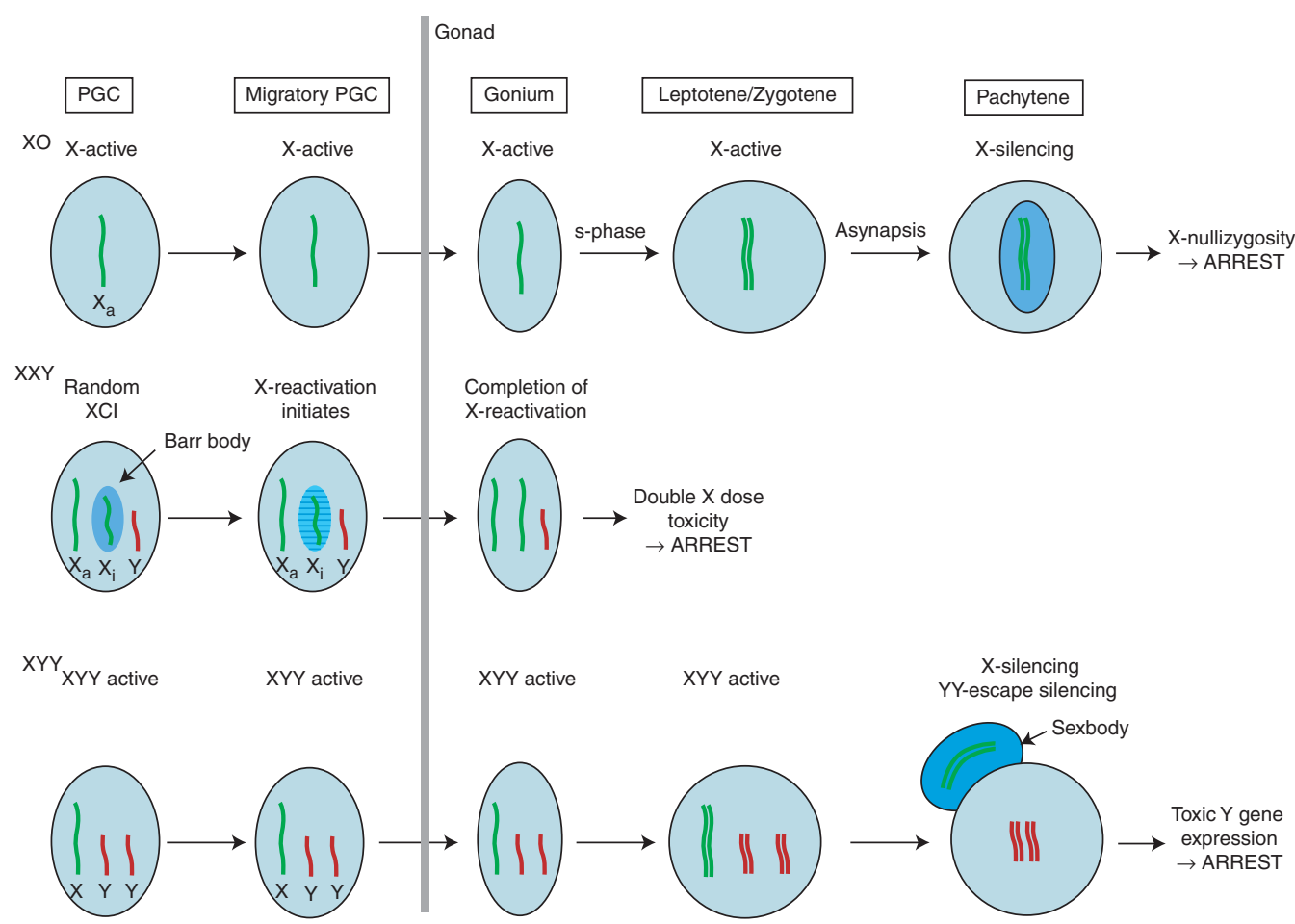

Figure 3. A model for germ cell arrest in sex chromosome aneuploid conditions. In XO females, XCI does not take place during early development, the X chromosome is therefore active until pachytene. At this stage, the unsynapsed state of the $\mathrm{X}$ chromosome triggers meiotic silencing; the resulting inactivation of X-linked genes leads to pachytene arrest. In XXY males, the presence of two X chromosomes initiates random XCI in the epiblast; PGCs therefore have one inactive $\mathrm{X}$. The exact timing of X chromosome reactivation during germ cell development is unclear, but may follow similar kinetics to that in XX females. The resulting double dose of Xlinked gene expression causes spermatogonial arrest. In XYY males, all three sex chromosomes are active until pachytene. At this stage, the X chromosome undergoes MSCI because it is unsynapsed. However, the two Y chromosomes undergo synapsis and therefore escape silencing; the resulting sustained expression of Y-linked genes is toxic and leads to pachytene arrest.

are eliminated during mid-pachytene, whereas those harboring completely unsynapsed, and hence fully silenced $\mathrm{X}$ and $\mathrm{Y}$ chromosomes, are able to progress to late pachytene (Turner et al. 2006). These findings are consistent with a model in which escape from MSCI causes germ cell arrest, presumably because of the toxic effects of misexpression of one or more genes on the Y chromosome (Fig. 3). This model has recently been corroborated: Preventing $\mathrm{Y}-\mathrm{Y}$ synapsis in XYY males circumvents this mid-pachytene block (Royo et al. 2010). Furthermore, forced expression of Y-linked genes during mid-pachytene in XY males causes a meiotic block indistinguishable from that seen in XYY males (Royo et al. 2010). Independent evidence that MSCI is essential for transition through pachytene comes from Brcal and H2AX null males; in both cases there is a meiotic block and the stage of germ cell arrest phenocopies that seen in XYY males (i.e., mid-pachytene [Turner et al. 2004; Fernandez-Capetillo et al. 2003]). Thus illegitimate YY synapsis drives meiotic failure in Double Y syndrome mice and men.

The sex chromosome abnormalities so far discussed are an unusually common cause of infertility in men. Most of the remaining cases are classed as idiopathic; however, even here as yet uncharacterized genetic defects affecting 
the sex chromosomes may be responsible. In particular, mutation screens have focused predominantly on the Y chromosome, because of its male specificity and enrichment for spermatogenesis genes. However, we now know that the $\mathrm{X}$ chromosome is also enriched in spermatogenesis genes, with many having roles in spermatogonial differentiation (predominantly single-copy genes) and others in spermiogenesis (predominantly multiple-copy genes). Mutations in spermatogonial-specific X-linked genes could predispose to infertility associated with early germ cell arrest, whereas copy number loss or gain in the highly amplified spermatid-expressed genes could cause late spermatogenic phenotypes.

\section{DISCUSSION}

In this article we have highlighted the very dynamic behavior of the sex chromosomes in the mammalian germline, as well as the impact that an incorrect dosage of X- or Y-linked genes can have on fertility. The sex chromosomes have a unique genetic constitution because of the specific evolutionary pressures that they are under. They also undergo unique processes, including meiotic XY inactivation in the male germline and $\mathrm{X}$ chromosome inactivation in the female soma. Numerous questions and hypotheses remain to be explored in this area. For example, what is the exact role of meiotic inactivation? Can sterility in $\mathrm{XO}$ females be rescued in if meiotic inactivation is abolished? Do men with early spermatogenic blocks harbor mutations in single copy X linked genes? Does dampening the expression of pachytene-toxic Y genes rescue germ cell losses in XYY males? Answers to such questions should be of profound importance to our understanding of infertility.

\section{REFERENCES}

Andina RJ. 1978. A study of X chromosome regulation during oogenesis in the mouse. Exp Cell Res 111: 211-218.

Ashley T. 2000. An integration of old and new perspectives of mammalian meiotic sterility. In Results and problems in cell differentiation, Vol. 2 (ed. McElreavey K), pp. 131-173. Springer-Verlag, Berlin.
Baarends WM, Hoogerbrugge JW, Roest HP, Ooms M, Vreeburg J, Hoeijmakers JH, Grootegoed JA. 1999. Histone ubiquitination and chromatin remodeling in mouse spermatogenesis. Dev Biol 207: 322-333.

Baarends WM, Wassenaar E, van der Laan R, Hoogerbrugge J, Sleddens-Linkels E, Hoeijmakers JH, de Boer P, Grootegoed JA. 2005. Silencing of unpaired chromatin and histone $\mathrm{H} 2 \mathrm{~A}$ ubiquitination in mammalian meiosis. Mol Cell Biol 25: 1041-1053.

Baudat F, de Massy B. 2007. Regulating double-stranded DNA break repair towards crossover or non-crossover during mammalian meiosis. Chromosome Res 15: 565577.

Bean CJ, Schaner CE, Kelly WG. 2004. Meiotic pairing and imprinted X chromatin assembly in Caenorhabditis elegans. Nat Genet 36: 100-105.

Bellani MA, Romanienko PJ, Cairatti DA, Camerini-Otero RD. 2005. SPO11 is required for sex-body formation, and Spo11 heterozygosity rescues the prophase arrest of $\mathrm{Atm}^{-/-}$spermatocytes. J Cell Sci 118: 3233-3245.

Betran E, Thornton K, Long M. 2002. Retroposed new genes out of the X in Drosophila. Genome Res 12: 1854-1859.

Blanco P, Shlumukova M, Sargent CA, Jobling MA, Affara N, Hurles ME. 2000. Divergent outcomes of intrachromosomal recombination on the human Y chromosome: Male infertility and recurrent polymorphism. J Med Genet 37: $752-758$.

Burgoyne PS, Baker TG. 1981. Oocyte depletion in XO mice and their XX sibs from 12 to 200 days post partum. J Reprod Fertil 61: 207-212.

Burgoyne PS, Baker TG. 1985. Perinatal oocyte loss in XO mice and its implications for the aetiology of gonadal dysgenesis in XO women. J Reprod Fertil 75: 633-645.

Cabrero J, Teruel M, Carmona FD, Jiménez R, Camacho JP. 2002. Histone H3 lysine 9 acetylation pattern suggests that $\mathrm{X}$ and $\mathrm{B}$ chromosomes are silenced during entire male meiosis in a grasshopper. Cytogenet Genome Res 119: $135-142$.

Chandley AC. 1997. Karyotype and oligospermia. In Genetics of human male fertility (ed. Barratt C, et al.), pp. 111-122. Editions EDK, Paris.

Charlesworth B, Charlesworth D. 2000. The degeneration of Y chromosomes. Philos Trans R Soc Lond B Biol Sci 355: $1563-1572$.

Chen B, Chu T, Harms E, Gergen JP, Strickland S. 1998. Mapping of Drosophila mutations using site-specific male recombination. Genetics 149: 157-163.

Chuva de Sousa Lopes SM, Hayashi K, Shovlin TC, Mifsud W, Surani MA, McLaren A. 2008. X chromosome activity in mouse XX primordial germ cells. PLoS Genet 4: e30.

Cocquet J, Ellis PJ, Yamauchi Y, Mahadevaiah SK, Affara NA, Ward MA, Burgoyne PS. 2009. The multicopy gene Sly represses the sex chromosomes in the male mouse germline after meiosis. PLoS Biol 7: e1000244.

Cocquet J, Ellis PJ, Yamauchi Y, Riel JM, Karacs TP, Rattigan A, Ojarikre OA, Affara NA, Ward MA, Burgoyne PS. 2010. The multicopy gene Sly represses the sex chromosomes in the male mouse after meiosis. PLoS Biology 7: e1000244.

De Kretser DM. 1997. Male infertility. Lancet 349: 787-790. 
de Napoles M, Mermoud JE, Wakao R, Tang YA, Endoh M, Appanah R, Nesterova TB, Silva J, Otte AP, Vidal M, et al. 2004. Polycomb group proteins Ring1A/B link ubiquitylation of histone $\mathrm{H} 2 \mathrm{~A}$ to heritable gene silencing and $\mathrm{X}$ inactivation. Dev Cell 7: 663-676.

de Napoles M, Nesterova T, Brockdorff N. 2007. Early loss of Xist RNA expression and inactive $\mathrm{X}$ chromosome associated chromatin modification in developing primordial germ cells. PLoS One 2: e860.

Emerson JJ, Kaessmann H, Betran E, Long M. 2004. Extensive gene traffic on the mammalian X chromosome. Science 303: 537-540.

Ellis PJ, Clemente EJ, Ball P, Touré A, Ferguson L, Turner JM, Loveland KL, Affara NA, Burgoyne PS. 2005. Deletions on mouse Yq lead to upregulation of multiple X- and Y-linked transcripts in spermatids. Hum Mol Genet 14: 2705-2715.

Epstein CJ. 1969. Mammalian oocytes: X chromosome activity. Science 163: 1078-1079.

Heard E, Disteche CM. 2006. Dosage compensation in mammals: Fine-tuning the expression of the X chromosome. Genes Dev 20: 1848-1867.

Fang J, Chen T, Chadwick B, Li E, Zhang Y. 2004. Ringlb-mediated H2A ubiquitination associates with inactive $\mathrm{X}$ chromosomes and is involved in initiation of X inactivation. J Biol Chem 279: 52812-52815.

Ferguson-Smith MA. 1959. The prepubertal testicular lesion in chromatin-positive Klinefelter's syndrome ( primary micro-orchidism) as seen in mentally handicapped children. Lancet 1: 219-222.

Ferlin A, Arredi B, Foresta C. 2006. Genetic causes of male infertility. Reprod Toxicol 22: 133-141.

Fernandez-Capetillo O, Mahadevaiah SK, Celeste A, Romanienko PJ, Camerini-Otero RD, Bonner WM, Manova K, Burgoyne P, Nussenzweig A. 2003. H2AX is required for chromatin remodeling and inactivation of sex chromosomes in male mouse meiosis. Dev Cell 4: 497-508.

Fillingham J, Keogh MC, Krogan NJ. 2006. $\gamma \mathrm{H} 2 \mathrm{AX}$ and its role in DNA double-strand break repair. Biochem Cell Biol 84: 568-577.

Fisher RA. 1931. The evolution of dominance. Biol Rev 6: 345-368.

Foresta C, Moro E, Ferlin A. 2001. Prognostic value of Y deletion analysis. The role of current methods. Hum Reprod 16: 1543-1547.

Garcia-Cruz R, Roig I, Robles P, Scherthan H, Garcia Caldés M. 2009. ATR, BRCA1 and $\gamma \mathrm{H} 2 \mathrm{AX}$ localize to unsynapsed chromosomes at the pachytene stage in human oocytes. Reprod Biomed Online 18: 37-44.

Gartler SM, Andina R, Gant N. 1975. Ontogeny of X chromosome inactivation in the female germline. Exp Cell Res 91: $454-457$.

Greaves IK, Rangasamy D, Devoy M, Marshall Graves JA, Tremethick DJ. 2006. The X and Y chromosomes assemble into H2A.Z, containing facultative heterochromatin, following meiosis. Mol Cell Biol 26: 5394-5405.

Hall H, Hunt P, Hassold T. 2006. Meiosis and sex chromosome aneuploidy: How meiotic errors cause aneuploidy; how aneuploidy causes meiotic errors. Curr Opin Genet Dev 16: $323-329$.
Hamer G, Kal HB, Westphal CH, Ashley T, de Rooij DG. 2004. Ataxia telangiectasia mutated expression and activation in the testis. Biol Reprod 70: 1206-1212.

Hassold T, Hunt P. 2001. To err (meiotically) is human: The genesis of human aneuploidy. Nat Rev Genet 2: 280-291.

Heard E, Disteche CM. 2006. Dosage compensation in mammals: Fine-tuning the expression of the $\mathrm{X}$ chromosome. Genes Dev 20: 1848-1867.

Heller CG, Clermont Y. 1963. Spermatogenesis in man: An estimate of its duration. Science 140: 184-186.

Hendriksen PJ. 1999. Do X and Y spermatozoa differ in proteins? Theriogenology 52: 1295-1307.

Hendriksen PJ, Hoogerbrugge JW, Themmen AP, Koken MH, Hoeijmakers JH, Oostra BA, van der Lende T, Grootegoed JA. 1995. Postmeiotic transcription of X and Y chromosomal genes during spermatogenesis in the mouse. Dev Biol 170: 730-733.

Hense W, Baines JF, Parsch J. 2007. X chromosome inactivation during Drosophila spermatogenesis. PLoS Biol 5: e273.

Hoyer-Fender S, Costanzi C, Pehrson JR. 2000. Histone macroH2A1.2 is concentrated in the XY-body by the early pachytene stage of spermatogenesis. Exp Cell Res 258: 254-260.

Hsu LY. 1994. Phenotype/karyotype correlations of Y chromosome aneuploidy with emphasis on structural aberrations in postnatally diagnosed cases. Am J Med Genet 53: $108-140$.

Hunter N, Börner GV, Lichten M, Kleckner N. 2001 $\gamma$-H2AX illuminates meiosis. Nat Genet 27: 236-238.

Jacobs PA, Ross A. 1966. Structural abnormalities of the Y chromosome in man. Nature 210: 352-354.

Jacobs P, Dalton P, James R, Mosse K, Power M, Robinson D, Skuse D. 1997. Turner syndrome: A cytogenetic and molecular study. Ann Hum Genet 61: 471-483.

Kamp C, Hirschmann P, Voss H, Huellen K, Vogt PH. 2000. Two long homologous retroviral sequence blocks in proximal Yq11 cause $A Z F a$ microdeletions as a result of intrachromosomal recombination events. Hum Mol Genet 9: $2563-2572$.

Keeney S. 2001. Mechanism and control of meiotic recombination initiation. Curr Top Dev Biol 52: 1-53.

Khalil AM, Boyar FZ, Driscoll DJ. 2004. Dynamic histone modifications mark sex chromosome inactivation and reactivation during mammalian spermatogenesis. Proc Natl Acad Sci 101: 16583-16587.

Khil PP, Smirnova NA, Romanienko PJ, Camerini-Otero RD. 2004. The mouse $\mathrm{X}$ chromosome is enriched for sexbiased genes not subject to selection by meiotic sex chromosome inactivation. Nat Genet 36: 642-664.

Khil PP, Oliver B, Camerini-Otero RD. 2005. X for intersection: Retrotransposition both on and off the $\mathrm{X}$ chromosome is more frequent. Trends Genet 21: 3-7.

Kratzer PG, Chapman VM. 1981. X chromosome reactivation in oocytes of Mus caroli. Proc Natl Acad Sci 78: 3093-3097.

Kuroda-Kawaguchi T, Skaletsky H, Brown LG, Minx PJ, Cordum HS, Waterston RH, Wilson RK, Silber S, Oates $\mathrm{R}$, Rozen S, et al. 2001. The AZFc region of the Y chromosome features massive palindromes and uniform recurrent deletions in infertile men. Nat Genet 29: 279-286. 
Lange J, Skaletsky H, van Daalen SK, Embry SL, Korver CM, Brown LG, Oates RD, Silber S, Repping S, Page DC. 2009. Isodicentric $\mathrm{Y}$ chromosomes and sex disorders as byproducts of homologous recombination that maintains palindromes. Cell 138: 855-869.

Lercher MJ, Urrutia AO, Hurst LD. 2003. Evidence that the human X chromosome is enriched for male-specific but not female-specific genes. Mol Biol Evol 20: 1113-1116.

Lue Y, Rao PN, Sinha Hikim AP, Im M, Salameh WA, Yen PH, Wang C, Swerdloff RS. 2001. XXY male mice: An experimental model for Klinefelter syndrome. Endocrinology 142: 1461-1470.

Mahadevaiah SK, Evans EP, Burgoyne PS. 2000. An analysis of meiotic impairment and of sex chromosome associations throughout meiosis in XYY mice. Cytogenet Cell Genet 89: 29-37.

Mahadevaiah SK, Turner JM, Baudat F, Rogakou EP, de Boer P, Blanco-Rodriguez J, Jasin M, Keeney S, Bonner WM, Burgoyne PS. 2001. Recombinational DNA doublestrand breaks in mice precede synapsis. Nat Genet 27: 271-276.

Mahadevaiah SK, Bourc'his D, de Rooij DG, Bestor TH, Turner JM, Burgoyne PS. 2008. Extensive meiotic asynapsis in mice antagonises meiotic silencing of unsynapsed chromatin and consequently disrupts meiotic sex chromosome inactivation. J Cell Biol 182: 263-276.

Mak W, Nesterova TB, de Napoles M, Appanah R, Yamanaka S, Otte AP, Brockdorff N. 2004. Reactivation of the paternal X chromosome in early mouse embryos. Science 303: 666-669.

Marahrens Y, Panning B, Dausman J, Strauss W, Jaenisch R. 1997. Xist-deficient mice are defective in dosage compensation but not in spermatogenesis. Genes Dev 11: $156-166$.

Marshall Graves JA. 2002. The rise and fall of SRY. Trends Genet 18: 259-264.

Mazeyrat S, Saut N, Grigoriev V, Mahadevaiah SK, Ojarikre OA, Rattigan A, Bishop C, Eicher EM, Mitchell MJ, Burgoyne PS. 2001. A Y-encoded subunit of the translation initiation factor Eif2 is essential for mouse spermatogenesis. Nat Genet 29: 49-53.

McCarrey JR, Dilworth DD, Sharp RM. 1992. Semiquantitative analysis of $\mathrm{X}$-linked gene expression during spermatogenesis in the mouse: Ethidium-bromide staining of RT-PCR products. Genet Anal Tech Appl 9: 117-123.

McLaren A. 2003. Primordial germ cells in the mouse. Dev Biol 262: 1-15.

McKee BD, Handel MA. 1993. Sex chromosomes, recombination, and chromatin conformation. Chromosoma 102: 71-80.

McMahon A, Monk M. 1983. X-chromosome activity in female mouse embryos heterozygous for Pgk-1 and Searle's translocation, T(X;16)16H. Genet Res Camb 41: 69-83.

Metzler-Guillemain C, Luciani J, Depetris D, Guichaoua MR, Mattei MG. 2003. HP1 $\beta$ and HP1 $\gamma$, but not HP $1 \alpha$, decorate the entire XY body during human male meiosis. Chromosome Res 11: 73-81.

Mitchell MJ. 2004. Spermatogenesis and the mouse Y chromosome: Specialisation out of decay. Results Probl Cell Differ 28: 233-270.
Mueller JL, Mahadevaiah SK, Park PJ, Warburton PE, Page DC, Turner JM. 2008. The mouse X chromosome is enriched for multicopy testis genes showing postmeiotic expression. Nat Genet 40: 794-799.

Monesi V. 1965. Differential rate of ribonucleic acid synthesis in the autosomes and sex chromosomes during male meiosis in the mouse. Chromosoma 17: 11-21.

Monk M, McLaren A. 1981. X-chromosome activity in foetal germ cells of the mouse. J Embryol Exp Morph 63: $75-84$.

Motzkus D, Singh PB, Hoyer-Fender S. 1999. M31, a murine homolog of Drosophila HP1, is concentrated in the XY body during spermatogenesis. Cytogenet Cell Genet 86: 83-88.

Mroz K, Carrel L, Hunt PA. 1999. Germ cell development in the XXY mouse: Evidence that X chromosome reactivation is independent of sexual differentiation. Dev Biol 207: 229-238.

Namekawa SH, Park PJ, Zhang LF, Shima JE, McCarrey JR, Griswold MD, Lee JT. 2006. Postmeiotic sex chromatin in the male germline of mice. Curr Biol 16: 660-667.

Nesterova TB, Mermoud JE, Hilton K, Pehrson J, Surani MA. 2002. Xist expression and macroH2A12 localisation in mouse primordial and pluripotent embryonic germ cells. Differentiation 69: 216-225.

Odartchenko N, Pavillard M. 1970. Late DNA replication in male mouse meiotic chromosomes. Science 167: $1133-1134$.

Okamoto I, Otte AP, Allis CD, Reinberg D, Heard E. 2004. Epigenetic dynamics of imprinted $\mathrm{X}$ inactivation during early mouse development. Science 303: 644-649.

Parisi M, Nuttall R, Naiman D, Bouffard G, Malley J, Andrews J, Eastman S, Oliver B. 2003. Paucity of genes on the Drosophila X chromosome showing male-biased expression. Science 299: 697-700.

Penny GD, Kay GF, Sheardown SA, Rastan S, Brockdorff N. 1996. Requirement for Xist in X chromosome inactivation. Nature 379: 131-137.

Peters AH, O'Carroll D, Scherthan H, Mechtler K, Sauer S, Schofer C, Weipoltshammer K, Pagani M, Lachner M, Kohlmaier A, et al. 2001. Loss of the Suv39h histone methyltransferases impairs mammalian heterochromatin and genome stability. Cell 107: 323-337.

Plath K, Fang J, Mlynarczyk-Evans SK, Cao R, Worringer KA, Wang H, de la Cruz CC, Otte AP, Panning B, Zhang Y. 2003. Role of histone H3 lysine 27 methylation in X inactivation. Science 300: 131-135.

Rastan S. 1982. Timing of X-chromosome inactivation in postimplantation mouse embryos. J Embryol Exp Morphol 71: 11.

Ranz JM, Castillo-Davis CI, Meiklejohn CD, Hartl DL. 2003. Sex-dependent gene expression and evolution of the Drosophila transcriptome. Science 300: 1742-1745.

Reinke V, Gil IS, Ward S, Kazmer K. 2004. Genome-wide germline-enriched and sex-biased expression profiles in Caenorhabditis elegans. Development 131: 311-323.

Repping S, Skaletsky H, Lange J, Silber S, Van Der Veen F, Oates RD, Page DC, Rozen S. 2002. Recombination between palindromes P5 and P1 on the human Y chromosome causes massive deletions and spermatogenic failure. Am J Hum Genet 71: 906-922. 
Repping S, Skaletsky H, Brown L, van Daalen SK, Korver CM, Pyntikova T, Kuroda-Kawaguchi T, de Vries JW, Oates RD, Silber S, et al. 2003. Polymorphism for a 1.6-Mb deletion of the human Y chromosome persists through balance between recurrent mutation and haploid selection. Nat Genet 35: 247-251.

Reynard LN, Turner JM. 2009. Increased sex chromosome expression and epigenetic abnormalities in spermatids from male mice with Y chromosome deletions. J Cell Sci 122: 4239-4248.

Reynard LN, Cocquet J, Burgoyne PS. 2009. The multicopy mouse gene Sycp3-like Y-linked (Sly) encodes an abundant spermatid protein that interacts with a histone acetyltransferase and an acrosomal protein. Biol Reprod 81: $250-257$.

Rice WR. 1984. Sex-chromosomes and the evolution of sexual dimorphism. Evolution 38: 735-742.

Ro S, Park C, Sanders KM, McCarrey JR, Yan W. 2007. Cloning and expression profiling of testis-expressed microRNAs. Dev Biol 311: 592-602.

Robinson DO, Jacobs PA. 1999. The origin of the extra Y chromosome in males with a 47,XYY karyotype. Hum Mol Genet 8: 2205-2209.

Rodriguez TA, Burgoyne PS. 2000. Evidence that sex chromosome asynapsis, rather than excess $\mathrm{Y}$ gene dosage, is responsible for the meiotic impairment of XYY mice. Cytogenet Cell Genet 89: 38-43.

Rogakou EP, Boon C, Redon C, Bonner WM. 1999. Megabase chromatin domains involved in DNA double-strand breaks in vivo. J Cell Biol 146: 905-916.

Rogers RS, Inselman A, Handel MA, Matunis MJ. 2004 SUMO modified proteins localize to the XY body of pachytene spermatocytes. Chromosoma 113: 233-243.

Royo H, Polikiewicz G, Mahadevaiah SK, Prosser H, Mitchell M, Bradley A, de Rooij DG, Burgoyne PS, Turner JM. 2010. Evidence that meiotic sex chromosome inactivation is essential for male fertility. Curr Biol 20: 2117-2123.

Rozen S, Skaletsky H, Marszalek JD, Minx PJ, Cordum HS, Waterston RH, Wilson RK, Page DC. 2003. Abundant gene conversion between arms of palindromes in human and ape Y chromosomes. Nature 423: 873-876.

Russell LD, Ettlin RA, Sinha Hikim AP, Clegg ED. 1990. Histological and histopathological evaluation of the testis (ed. Russell LD, et al.), pp. 1-40. Cache River Press, Clearwater, FL.

Saitou M. 2009. Germ cell specification in mice. Curr Opin Genet Dev 19: 386-395.

Schoenmakers S, Wassenaar E, van Cappellen WA, Derijck AA, de Boer P, Laven JS, Grootegoed JA, Baarends WM 2008. Increased frequency of asynapsis and associated meiotic silencing of heterologous chromatin in the presence of irradiation-induced extra DNA double strand breaks. Dev Biol 317: 270-281.

Schoenmakers S, Wassenaar E, Hoogerbrugge JW, Laven JS, Grootegoed JA, Baarends WM. 2009. Female meiotic sex chromosome inactivation in chicken. PLoS Genet 5: e1000466.

Shi Q, Martin RH. 2000. Multicolor fluorescence in situ hybridization analysis of meiotic chromosome segregation in a $47, \mathrm{XYY}$ male and a review of the literature. $A m \mathrm{~J}$ Med Genet 93: 40-46.

Shiu PK, Raju NB, Zickler D, Metzenberg RL. 2001. Meiotic silencing by unpaired DNA. Cell 107: 905-916.

Silva J, Mak W, Zvetkova I, Appanah R, Nesterova TB, Webster Z, Peters AH, Jenuwein T, Otte AP, Brockdorff N. 2003. Establishment of histone h3 methylation on the inactive $\mathrm{X}$ chromosome requires transient recruitment of Eed-Enx1 polycomb group complexes. Dev Cell 4: 481-495.

Singer-Sam J, Robinson MO, Bellvé AR, Simon MI, Riggs AD. 1990. Measurement by quantitative PCR of changes in HPRT, PGK-1, PGK-2, APRT, MTase, and Zfy gene transcripts during mouse spermatogenesis. Nucleic Acids Res 18: 1255-1259.

Skaletsky H, Kuroda-Kawaguchi T, Minx PJ, Cordum HS, Hillier L, Brown LG, Repping S, Pyntikova T, Ali J, Bier T, et al. 2003. The male-specific region of the human $Y$ chromosome is a mosaic of discrete sequence classes. Nature 423: 825-837.

Solari AJ. 1974. The behavior of the XY pair in mammals. Rev Cytol 38: 273-317.

Solari AJ, Rey Valzacchi G. 1997. The prevalence of a YY synaptonemal complex over XY synapsis in an XYY man with exclusive XYY spermatocytes. Chromosome Res 5: 467-474.

Song R, Ro S, Michaels JD, Park C, McCarrey JR, Yan W. 2009. Many X-linked microRNAs escape meiotic sex chromosome inactivation. Nat Genet 41: 488-493.

Speed RM. 1986. Oocyte development in XO foetuses of man and mouse: the possible role of heterologous Xchromosome pairing in germ cell survival. Chromosoma 94: $115-124$.

Speed RM, Faed MJ, Batstone PJ, Baxby K, Barnetson W. 1991. Persistence of two Y chromosomes through meiotic prophase and metaphase I in an XYY man. Hum Genet 87: 416-420.

Speroff L, Glass RH, Kase NG. 1991. Assisted reproduction. In Clinical gynecologic endocrinology and infertility (ed. Speroff L, Glass RH, Kase NG), p. 1144. Lippincott Williams \& Wilkins, Baltimore.

Sugimoto M, Abe K. 2007. X chromosome reactivation initiates in nascent primordial germ cells in mice. PLoS Genet 3: e116.

Sun C, Skaletsky H, Rozen S, Gromoll J, Nieschlag E, Oates R, Page DC. 2000. Deletion of azoospermia factor a (AZFa) region of human $\mathrm{Y}$ chromosome caused by recombination between HERV15 proviruses. Hum Mol Genet 9: 2291-2296.

Szostak JW, Orr-Weaver TL, Rothstein RJ, Stahl FW. 1983. The double-strand-break repair model for recombination. Cell 33: 25-35.

Takagi N, Sugawara O, Sasaki M. 1982. Allocyclic early replicating X chromosome in mice: Genetic inactivity and shift into a late replicator in early embryogenesis. Chromosoma 85: 275.

Tam PPL, Zhou SX, Tan S-S. 1994. X-chromosome activity of the mouse primordial germ cells revealed by the expression of an X-linked lacZ transgene. Development 120: $2925-2932$. 
Function of the Sex Chromosomes in Mammalian Fertility

Thomas NS, Hassold TJ. 2003. Aberrant recombination and the origin of Klinefelter syndrome. Hum Reprod Update 9: 309-317.

Tiepolo L, Zuffardi O. 1976. Localization of factors controlling spermatogenesis in the nonfluorescent portion of the human Y chromosome long arm. Hum Genet 34: 119-124.

Toure A, Szot M, Mahadevaiah SK, Rattigan A, Ojarikre OA, Burgoyne PS. 2004. A new deletion of the mouse Y chromosome long arm associated with the loss of Ssty expression, abnormal sperm development and sterility. Genetics 166: $901-912$.

Toure A, Clemente EJ, Ellis P, Mahadevaiah SK, Ojarikre OA, Ball PA, Reynard L, Loveland KL, Burgoyne PS, Affara NA. 2005. Identification of novel Y chromosome encoded transcripts by testis transcriptome analysis of mice with deletions of the $\mathrm{Y}$ chromosome long arm. Genome Biol 6: R102.

Turner JM. 2007. Meiotic sex chromosome inactivation. Development 134: 1823-1831.

Turner JM, Aprelikova O, Xu X, Wang R, Kim S, Chandramouli GV, Barrett JC, Burgoyne PS, Deng CX. 2004. BRCA1, histone $\mathrm{H} 2 \mathrm{AX}$ phosphorylation, and male meiotic sex chromosome inactivation. Curr Biol 14: 2135-2142.

Turner JM, Mahadevaiah SK, Fernandez-Capetillo O, Nussenzweig A, Xu X, Deng CX, Burgoyne PS. 2005. Silencing of unsynapsed meiotic chromosomes in the mouse. Nat Genet 37: 41-47.

Turner JM, Mahadevaiah SK, Ellis PJ, Mitchell MJ, Burgoyne PS. 2006. Pachytene asynapsis drives meiotic sex chromosome inactivation and leads to substantial postmeiotic repression in spermatids. Dev Cell 10: 521-529. van der Heijden GW, Derijck AA, Pósfai E, Giele M, Pelczar P, Ramos L, Wansink DG, van der Vlag J, Peters AH, de Boer P. 2007. Chromosome-wide nucleosome replacement and H3.3 incorporation during mammalian meiotic sex chromosome inactivation. Nat Genet 39: 251-258.

Vigodner M. 2009. Sumoylation precedes accumulation of phosphorylated $\mathrm{H} 2 \mathrm{AX}$ on sex chromosomes during their meiotic inactivation. Chromosome Res 17: 37-45.

Vigodner M, Morris PL. 2005. Testicular expression of small ubiquitin-related modifier-1 (SUMO-1) supports multiple roles in spermatogenesis: Silencing of sex chromosomes in spermatocytes, spermatid microtubule nucleation, and nuclear reshaping. Dev Biol 282: $480-492$.

Vogt PH. 2005. AZF deletions and Y chromosomal haplogroups: History and update based on sequence. Hum Reprod Update 11: 319-336.

Vogt PH, Edelmann A, Kirsch S, Henegariu O, Hirschmann P, Kiesewetter F, Köhn FM, Schill WB, Farah S, Ramos C, et al. 1996. Human Y chromosome azoospermia factors (AZF) mapped to different subregions in Yq11. Hum Mol Genet 5: 933-943.

Wang PJ. 2004. X chromosomes, retrogenes and their role in male reproduction. Trends Endocrinol Metab 15: 79-83.

Wang PJ, McCarrey JR, Yang F, Page DC. 2001. An abundance of X-linked genes expressed in spermatogonia. Nat Genet 27: 422-426.

Zheng K, Yang F, Wang PJ. 2009. Regulation of male fertility by X-linked genes. J Androl 31: 79-85.

Zickler D, Kleckner N. 1999. Meiotic chromosomes: Integrating structure and function. Annu Rev Genet 33: 603-754. 


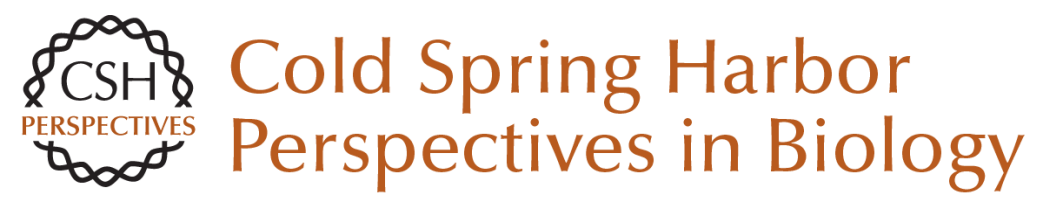

\section{Function of the Sex Chromosomes in Mammalian Fertility}

Edith Heard and James Turner

Cold Spring Harb Perspect Biol 2011; doi: 10.1101/cshperspect.a002675 originally published online July 5, 2011

\section{Subject Collection Germ Cells}

RNA Granules in Germ Cells Ekaterina Voronina, Geraldine Seydoux, Paolo Sassone-Corsi, et al.

Function of the Sex Chromosomes in Mammalian Fertility Edith Heard and James Turner

Small Noncoding RNAs in the Germline Jonathan P. Saxe and Haifan Lin

Mammalian Genomic Imprinting Marisa S. Bartolomei and Anne C. Ferguson-Smith

Molecular Regulation of the Mitosis/Meiosis Decision in Multicellular Organisms Judith Kimble

Selection in the Rapid Evolution of Gamete Recognition Proteins in Marine Invertebrates Victor D. Vacquier and Willie J. Swanson
Developmental Control of Oocyte Maturation and Egg Activation in Metazoan Models Jessica R. Von Stetina and Terry L. Orr-Weaver

Translational Control in Oocyte Development Joel D. Richter and Paul Lasko

Unique Aspects of Transcription Regulation in Male Germ Cells

Helen White-Cooper and Irwin Davidson

Germ Cell Intercellular Bridges

Michael P. Greenbaum, Tokuko Iwamori, Gregory M. Buchold, et al.

Germline Stem Cells

Allan Spradling, Margaret T. Fuller, Robert E. Braun, et al.

Nuclear Transfer to Eggs and Oocytes J. B. Gurdon and lan Wilmut

For additional articles in this collection, see http://cshperspectives.cshlp.org/cgi/collection/

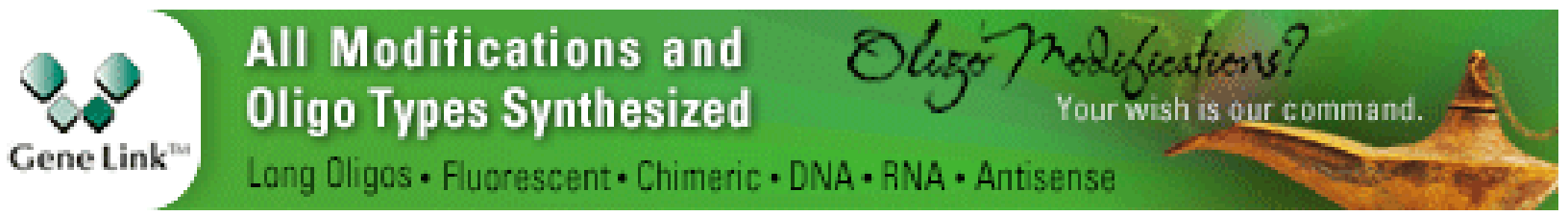

Copyright @ 2011 Cold Spring Harbor Laboratory Press; all rights reserved 